\title{
Tradição e Retórica Imagética: a construção da propaganda visual oposicionista no levante de 1932 em São Paulo
}

\section{Tradition and rhetorical image: a building of opposition visual advertising in São Paulo 1932 Revolt.}

\section{João Paulo RODRIGUES*}

\begin{abstract}
Resumo: Esgotando-se o tempo de vida das testemunhas do levante de 1932 o dever de memória respeitante a ele segue candente. Com efeito, a intensidade deste movimento perpassa, também, a historiografia, que aparece cindida em posições mais críticas ou aclamativas, reproduzindo, de certo modo, as polêmicas nascidas no próprio confronto. Em boa medida, por conseguinte, conhecer melhor a "Revolução Constitucionalista” implica exumar as leituras que os insurrectos faziam da realidade vivida e as representações de que lançavam mão, com vistas a vencer as correlações de forças que os acometiam. Essas preocupações são abordadas neste artigo, que o faz, no entanto, sob o prisma alvissareiro das imagens e da produção cultural vinculada à propaganda proselitista. São elas que trazem à tona a retórica constitucionalista, eivada por teores regionalistas, sustentada por redes de relações sociais e, dadas às sutilezas, imiscuídas profundamente na memória histórica.
\end{abstract}

Palavras-chave: Propaganda constitucionalista. Imagens. Levante de 1932.

\begin{abstract}
As the last remaining witnesses of the 1932 Revolt pass away, their memories remain aglow. Indeed, the intensity of this movement expresses itself in the historiography where we find critical and favorable positions reproducing controversies born out of the confrontation itself. To comprehend the "Constitutionalist Revolution" better means to resurrect the readings and representations of the rebels themselves, overcoming the forces attacking them. These concerns are approached in this article by analyzing the images and the cultural production linked to proselytizing propaganda. They reveal the constitutionalist rhetoric infected by regionalist tenets, maintained by social networking and, subtly blended deeply into historical memory.
\end{abstract}

\footnotetext{
* Professor Doutor - Departamento de História e de Pedagogia - Faculdade de Presidente Venceslau e Faculdade de Presidente Epitácio - UNIESP - União das Instituições Educacionais do Estado de São Paulo, Campi Pres. Venceslau e Pres. Epitácio - Rua Piracicaba, 47, CEP: 19400-000, Presidente Venceslau, São Paulo, Brasil. A pesquisa que resultou neste artigo contou com financiamento do CNPq. E-mail: perfejp@yahoo.com.br
} 
Tradição e Retórica Imagética: a construção da propaganda visual oposicionista no levante de 1932 em São Paulo

Keywords: Constitutionalist propaganda. Images. 1932 Revolt.

\section{Introdução}

Entre as principais ponderações de Pierre Francastel a respeito do campo visual está a assertiva de que as imagens, em suas diversas modalidades, não são instâncias alheias às demais contingências do vivido; ao contrário, ele postula que nelas operam códigos e protocolos interpretativos, cujos usos favorecem a intromissão, aparentemente despretensiosa, nos diversos âmbitos da sociedade.

Desenvolvendo um pouco mais seu argumento, Francastel explica que o artista, na tarefa intelectual de representar a realidade - visualmente ou valendo-se de outras linguagens -, não se limita a reproduzir os aspectos sociais mais candentes, uma vez que seria capaz de "nos oferecer o meio de penetrar mais profundamente nas energias do espírito" ao mesclar "elementos da realidade escolhidos no percebido imediato com elementos tirados das tradições imaginárias do indivíduo ou da sociedade" (FRANCASTEL, 1982, p.16).

Por caminhos distintos e limitando o enfoque analítico ao ato fotográfico, Boris Kossoy chega à conclusão equivalente. Em detrimento do suposto caráter testemunhal atribuído corriqueiramente às fotografias, equipara o papel do fotógrafo à ação de um "filtro cultural”, que se interpõe entre o cenário vivido, primeira realidade, e a cena captada, a qual encontra-se atravessada, por conseguinte, pela intencionalidade do autor da imagem, contratado ou não por terceiros, valendo-se de uma tecnologia específica e imortalizando da totalidade um fragmento espaçotemporal. Por estes motivos, Kossoy alerta para a necessidade de ir além da realidade aparente no documento visual, quando se almeja compreendê-lo. Afinal, tão importante quanto à apreensão do significado dos elementos retratados é a análise dos expurgos, dos cortes e da materialidade da fonte, que contribuem para preservar, rejeitar ou desvirtuar intencionalmente uma interpretação da realidade (KOSSOY, 2002).

Tendo em vista esses pressupostos teóricos, neste artigo almeja-se trazer para o debate algumas questões que recobrem os usos retóricos de imagens e o papel de certos intelectuais e artistas em setores estratégicos do levante paulista de 1932, acenando, de passagem, para o reverberar desta problemática no processo de construção da memória.

Em suma, trata-se de investigar a constituição e difusão paulatina de uma leitura da conjuntura social por opositores do tenentismo em São Paulo nos limiares de 1932, a partir de 
representações visuais veiculadas em panfletos e jornais. Em seguida, já no período do levante, abordar-se-á a contribuição indispensável dos produtores de signos culturais, no sentido de fortalecer e tornar hegemônica a retórica imagética formulada, questionando a respeito das redes de sociabilidade que permitem o ingresso à causa e a margem de liberdade a criação artística por parte do comitê diretivo. Por fim, a atenção recairá sobre as nuances concretas da propaganda visual materializada nos cartões postais constitucionalistas desvelando, sob o suposto caráter testemunhal das imagens, os apelos regionalistas que favorecem a recepção e plasmam as memórias.

\section{A constituição da imagem oposicionista: Liga de Defesa Paulista e Frente Única Paulista em}

\section{cena}

As tentativas de projetar às massas as manifestações oposicionistas de determinados segmentos da sociedade paulista contra o Governo Provisório de Getúlio Vargas abrangeram diversificadas formas ao longo da conflituosa relação entre eles, ${ }^{1}$ notadamente no âmbito do emprego de recursos retóricos e visuais. Desde fotografias divulgadas pela imprensa - muito antes do confronto armado - até selos de correspondência, entre outros, foram acionados com o propósito de constituir uma imagem positiva e atraente da campanha, a qual foi ganhando notoriedade tanto pela coloração política, como pelo acentuado matiz regionalista, afeito aos anseios de seus promotores.

Com efeito, já nos limiares de 1932, apresentar-se-iam boas ocasiões para enunciar no espaço público os traços desta representação proselitista e, dada a magnitude dos festejos que cercariam o aniversário de São Paulo, a realização de um grande comício, entre as efemérides, classificava-se como oportuna.

Para assegurar maior visibilidade ao evento, já amplamente divulgado pela imprensa periódica, à expressiva multidão - estimada em duzentas mil pessoas, ${ }^{2}$ que se reuniu sob chuva torrencial na Praça da Sé, em 25 de janeiro - congregar-se-ia a fina flor de políticos, militares, jornalistas e intelectuais de São Paulo. Gente que, em boa medida, se opusera, obstinadamente, às diretrizes político-econômicas tenentistas e vinha se articulando, desde então, em entidades como a Liga de Defesa Paulista (LDP), ${ }^{3}$ a fim de jungir forças para fazer frente aos que classificavam como “arrivistas do Catete”. Diante disso, a efeméride converter-se-ia, como se pode supor, em evento político.

Ainda que não tenham sido preservados registros orais dos festejos, as imagens captadas pela imprensa paulista permitem adentrar ao universo simbólico da ocasião. Na fotografia abaixo 
estão afixados elementos chamados a fazer parte da interpretação transmitida e, também, pistas emblemáticas para compreender a organização do meeting oposicionista:



FIGURA 1: Comício em 25/01/1932.

Fonte: PONTES, J. A. V., 2004, p.78.

A despeito do excesso de faixas envergadas pelo grupo que está à frente do comício, parece clara a intenção de explicar ao povo do Estado os fatos políticos posteriores à Revolução de 1930 e alertá-lo quanto aos rumos a serem preconizados. Para tanto, salta aos olhos a estratégia de investir em ideias-força a serem assimiladas pela população, sintetizando os discursos verbais, certamente inflamados, e tornando-os mais atraentes à visão. Nesse sentido, não é casual Constituição e Ordem aparecerem em destaque, em plena festa de São Paulo.

Mais do que palavrório vazio, esses termos concatenam uma leitura da realidade vivida, de acordo com a perspectiva de um Estado que perdera o poder e as benesses desfrutadas até 1930 e não se resignava a tal situação. Assim, se ordem pode canalizar diferentes expectativas, abrangendo desde o fim do governo discricionário até o combate às ideias "extremistas” do comunismo, cuja disseminação nacional era atribuída ao tenentismo, ${ }^{4}$ o termo Constituição não tem menos ressonância entre os contemporâneos, incidindo sobre as indispensáveis garantias inerentes ao Estado de Direito, em âmbito estadual e federal.

O caráter oposicionista e de afronta com que se representa a festa de São Paulo, tendo em vista a presença do interventor tenentista ainda à frente do Estado, não se limita a isso. Sem levar em consideração sequer os propósitos pátrios dos revolucionários de trinta, a maior parte dos 
slogans que se ostenta na imagem, assim como dos símbolos visuais e bandeiras empunhadas no dia de São Paulo evoca a tradição regional e apela para a defesa do território, como solução para todos os impasses sociais. Afinal, afirma-se, sem pudores, que "O esplendor de S. Paulo depende dos paulistas" e, na sequência, transcende-se à ação, conclamando "Hoje como no passado, paulistas avante!”.

Ora, ao que parece a LDP, a festa de São Paulo foi convertida em reduto de violentos ataques políticos, cujo sentido se caracteriza, em ambivalência, pela acentuação dos diversos problemas enfrentados pelo Estado e pelo país à época ${ }^{5}$ e a atribuição exclusiva dos mesmos à ação do tenentismo. Por certo, nesta visão, a parcela de culpa dos políticos paulistas era insignificante e não deveria ser lembrada. E, por fim, a manobra interpretativa seria ainda mais ardilosa ao conduzir as insatisfações que eram difusas em direção unívoca por ela arquitetada, ou seja, apoiar os líderes paulistas rumo à Constituinte passa a ser a senda idílica capaz de fazer justiça às grandiosas tradições de São Paulo, celebradas na data solene.

Mediante esta hipótese, uma observação a mais merece destaque na Figura 1: enquanto a maior parte da multidão reunida é flagrada em posição de escuta, sem empunhar uma bandeira sequer, o grupo que ocupa as escadarias da catedral da Sé é que se vale de um universo de slogans e símbolos propondo o apelo e a representação visual contra o adversário. Este grupo, por sua vez, obviamente não fora composto de modo aleatório ou às vésperas da comemoração. Ele constituiu-se a partir da junção dos membros da LDP e dos partidos paulistas que, dias antes, haviam rompido publicamente com o tenentismo e estavam dispostos a destroná-lo ${ }^{6}$.

Evidencia-se, com isso, que as diretrizes da campanha oposicionista em São Paulo são norteadas, desde o início, por entidades representativas da elite estadual. Delas parte a iniciativa de valer-se da comoção gerada pela festa cívica e pelos anseios diversos para transmitir uma interpretação politizada da conjuntura social, que se assenta claramente na exploração da tradição regional e na condenação ao tenentismo. O povo está presente em proporções expressivas para a época, na medida em que a cidade parou para acompanhar o comício, mas apresenta-se em posição de mero expectador da interpretação apresentada ${ }^{7}$.

Todavia, se é a LDP a articuladora deste diagnóstico laudatório e a população ainda não tomou em seus braços os símbolos da aquiescência, fica subjacente à análise a necessidade de se esclarecer o hiato entre os apelos da Liga e o fato consolidado, com os paulistas em armas no front. Com efeito, quais desafios se interpunham à recepção da imagem proselitista e que estratégias retóricas são fundamentais para conquistar a hegemonia do constitucionalismo? Como se erigiu, mediante o cenário acima explicitado, a ideia de que a "Revolução Constitucionalista” fora uma campanha de origem popular? 
Tradição e Retórica Imagética: a construção da propaganda visual oposicionista no levante de 1932 em São Paulo

As dificuldades para o êxito da investida parecem ter sido de grau mediano ao longo do extenso primeiro semestre de 1932. O próprio apelo à tradição regional que contribuiria para agregar multidões, incitando a revolta contra os problemas conjunturais, também abria margem a interpretações mais exacerbadas, que ameaçavam escapar aos liames da LDP. Dentro da Liga, aliás, havia discordâncias quanto à solução constitucionalista e perspectivas diferenciadas como o confederacionismo e até mesmo o separatismo.

Este era o caso, por exemplo, de Alfredo Ellis Junior, ex-deputado pelo Partido Republicano Paulista (PRP), proeminente intelectual da época, professor e um dos fundadores da LDP, que apesar disto, não fazia questão de ocultar sua opção pelo confederacionismo, sistema que só admitia o retorno à Constituição se esta resultasse na autonomia absoluta de São Paulo perante a nação, caso contrário, a separação seria um destino insofismável.

As ideias de Ellis Junior respeitantes a magnificência paulista dentro da federação foram apropriadas radicalmente por alunos dos cursos em que lecionava, dentre os quais se criou, ainda em janeiro de 1932, o jornalzinho clandestino O Separatista. A ilustração abaixo, divulgada no terceiro número da publicação que circulava trimestralmente, com tiragem incerta, demonstra o potencial explosivo da tradição e sinaliza para as aludidas dificuldades de implementar a leitura proposta pela LDP, sob os riscos da contrapropaganda:

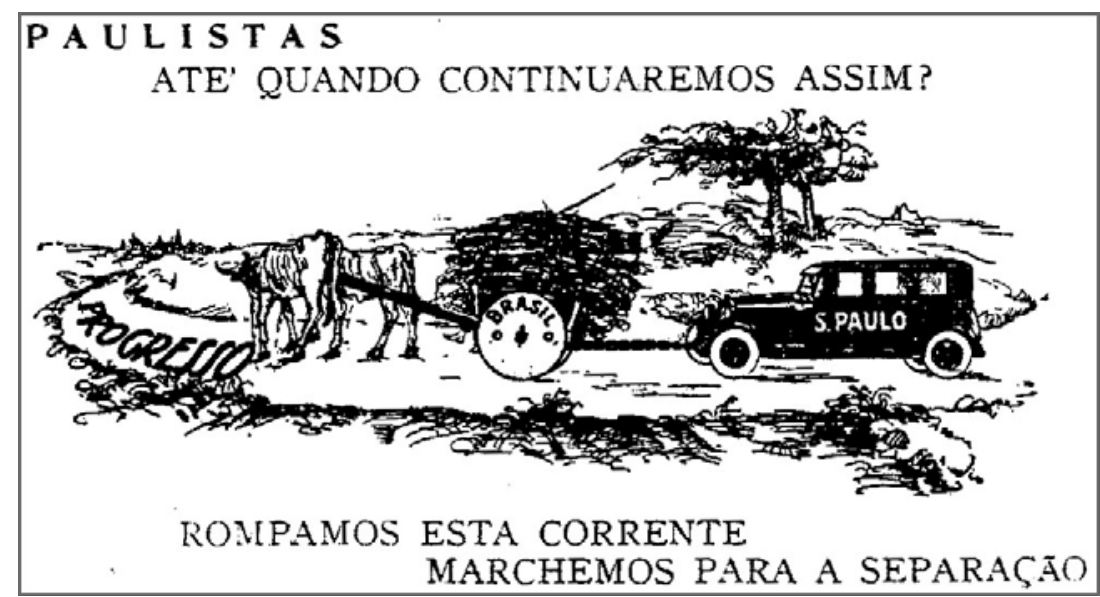

FIGURA 2: Panfleto separatista.

Fonte: O Separatista. Junho de 1932.

Entre as estratégias utilizadas pelos separatistas na representação imagética, é interessante observar o caráter abrangente dos conclames ao habitante de São Paulo. Em detrimento das formulações intelectuais tradicionais, que viam nas elites de quatro séculos as mais lídimas representantes da raça, o paulista evocado, entrementes, é o construtor da metrópole urbana, das indústrias e dos automóveis, seja ele nascido nesta nacionalidade seja imigrante, ${ }^{8}$ e que se vê numa 
situação de superioridade material em relação aos demais Estados da nação. Convidado a tomar uma posição diante disso, aconselha-se apenas a lógica, já que a simetria entre veículos tão díspares na estrada do progresso era inconcebível para ambos.

José Alfredo Vidigal Pontes (2004, p.172), assim como Jeziel De Paula (1999, p. 226-227), minimiza a importância das ideias separatistas em 1932, atribuindo-as a uma ala minoritária do PRP, sem, contudo, investigar a expressividade deste grupo na correlação de forças. As análises precisam avançar nesse sentido, afinal, o próprio chefe de polícia de São Paulo, Cordeiro de Farias, por temer o fortalecimento da propaganda lançaria comunicado proibindo e enrijecendo o combate aos “subversivos” separatistas:

É lamentável que de um caso regional se passe a um outro quase criminoso qual o do separatismo. O primeiro é perfeitamente defensável. Mas dahí a idea do desmembramento da Federação vae uma grande distancia. Por esse motivo, vou agir com a máxima energia até junto da imprensa para evitar que tal propaganda tome corpo e vulto. (CORREIO DA MANHÃ, 28/01/1932).

Seja como for, os indícios da presença separatista na cena exemplificam os óbices para a disseminação da representação oposicionista pela LDP. Tornar sua leitura da realidade hegemônica implicaria, deste modo, ajustar e simplificar ainda mais o diagnóstico, evitando os riscos de se dispersar em discussões teóricas sobre a natureza da Constituição ou de conjecturar complexos planos econômicos. Era preciso, no entendimento da LDP, ir além da mera compreensão dos fatos, e alcançar os sentimentos, os valores e o imaginário social. Por isso, a força da tradição regional aparece no cerne das disputas de poder nesta fase pacífica e de arregimentação da opinião pública, permeando as representações imagéticas. Como precioso bem simbólico, a paulistanidade é, então, perseguida, não por seu valor intrínseco, mas pela capacidade de “[...] duplicar e reforçar a dominação efetiva pela apropriação dos símbolos e garantir a obediência pela conjugação das relações de sentido e poderio” (BACZKO, 1984, p.299).

A tradição, por conseguinte, será vital em todos os passos da campanha, não apenas para designar o inimigo no plano simbólico e introjetar suavemente a retórica constitucionalista, mas, também, para superar as cisões interpretativas internas em prol ao caminho preconizado pela LDP. Nesse sentido, delimitar ao grande público o agente responsável pelas movimentações que vão ganhando corpo ao longo dos meses de fevereiro e março de 1932 se faz imprescindível, uma vez que a Liga passa a dividir espaço com diversas associações na batalha contra o tenentismo, 
sobretudo, a advinda da união dos dois principais partidos políticos de São Paulo: Partido Democrático (PD) e Partido Republicano Paulista (PRP), na Frente Única Paulista (FUP). LDP e FUP têm relações fluidas, seja na articulação de aliados interestaduais à causa constitucionalista ou na promoção de eventos proselitistas de massa.

Getúlio Vargas bem saberia se valer da participação dos partidos paulistas para denegrir a imagem da campanha, alegando que: “[...] elementos descontentes e ambiciosos tentam estabelecer a anarquia e a confusão em São Paulo [...]” (CORREIO DA MANHÃ, 12/07/1932).

Em contraposição à pecha de manipulação política, a LDP e a FUP novamente apelaram para a identidade regional. Valendo-se de discursos veementes na imprensa, notadamente no jornal O Estado de S. Paulo, também não abriram mão das vantagens da linguagem imagética, investindo em fotografias que enfatizavam a adesão popular e o seu envolvimento nas festas e encontros cívicos, que passaram a ser realizados com frequência nas datas comemorativas.

Nas Figuras 3 e 4, publicadas em jornais de expressiva circulação à época, apresentam-se dois episódios emblemáticos da ação oposicionista: o primeiro, no tumultuado dia 23 de maio de 1932, por ocasião da visita de Oswaldo Aranha, ministro da Fazenda do Governo Provisório, a São Paulo, com a incumbência de discutir a situação política do Estado. Na circunstância, as festividades costumeiras foram substituídas por manifestações de cobrança e resultaram em confrontos de rua entre adversários e defensores do tenentismo, a ponto de falecerem quatro constitucionalistas nos choques:

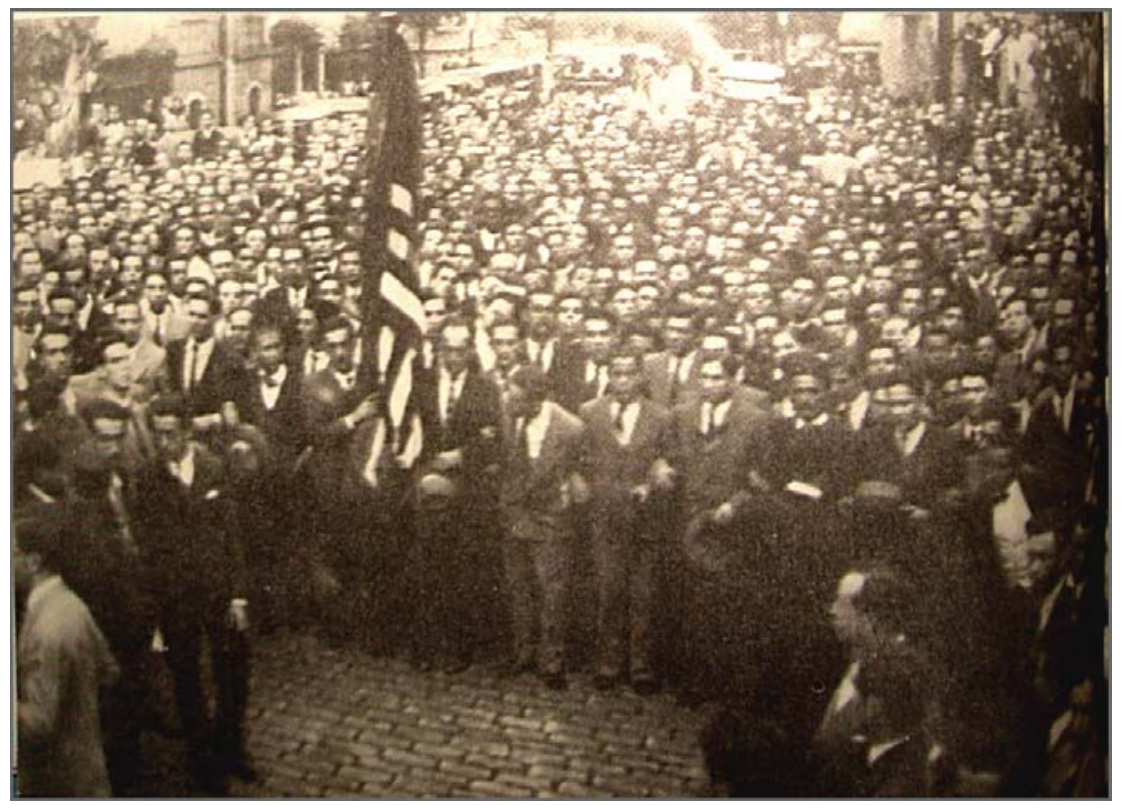

FIGURA 3: Manifestação Popular em 23 de maio de 1932. Fonte: MARTINS, 1954. 
A Figura 4, por sua vez, remete a 10 de julho, quando se desencadearia a aclamação popular de Pedro de Toledo, ex-interventor federal que se rebelara contra Getúlio Vargas e acedera ao posto de governador de São Paulo em beligerância:

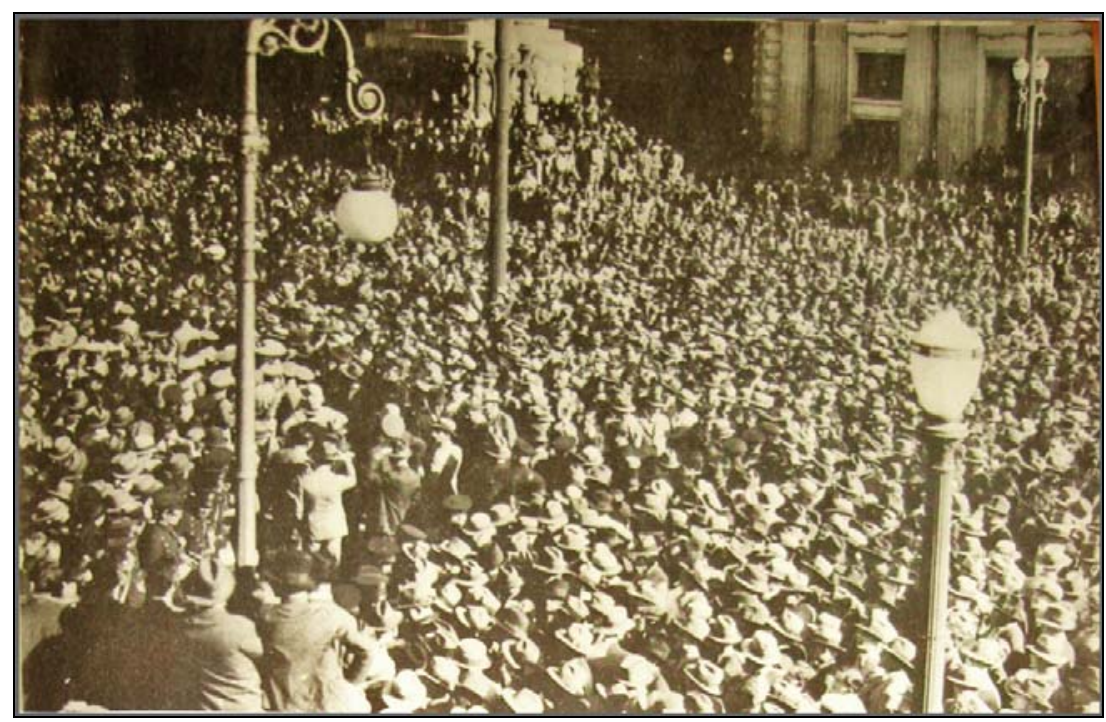

FIGURA 4: Cerimônia de Posse do Governador Pedro de Toledo. Fonte: MARTINS, 1954.

Em ambas as circunstâncias, embora envolvam acontecimentos de naturezas distintas, o enfoque conferido à imagem privilegia a grande comoção social supostamente trazida pelas ideias constitucionalistas. Porém, contrapondo-se ao habitual na cobertura jornalística, não são as personalidades preclaras em cima dos palanques da LDP ou os políticos de renome da FUP os protagonistas visados pelos fotógrafos. Ao contrário, o alvo é a vultosa multidão, em ação nas ruas e praças de São Paulo. Enquadrada ora frontalmente (figura 3) demonstrando pelos semblantes a sinceridade de propósitos, ora pelo alto e por trás (figura 4) com vistas a enfocar a extensão do contingente, que não é coagido pelas costas, tem-se a dimensão de um movimento de massa, grandioso e de improvável condução política.

O sentido literal da linguagem imagética coincide, portanto, com as intenções de seus produtores, como lembra Kossoy (2002), que, direcionando os grandes episódios da campanha à iniciativa popular - é o povo que luta e doa a vida por São Paulo em 23 de maio e, também, impõe Pedro de Toledo como governador -, enfraquecem a hipótese de manipulação política. Tais imagens têm, por conseguinte, a força de omitir e criar versões sobre a realidade. Ao seguir o curso desta interpretação, tem-se a impressão de que a correlação de forças que resultou na luta armada em 9 de julho não fora senão um impulso natural e espontâneo do povo de São Paulo, reivindicando livremente o que entendiam lhes ser de direito. 
Tradição e Retórica Imagética: a construção da propaganda visual oposicionista no levante de 1932 em São Paulo

Essa visão, longe de se limitar às imagens analisadas, é recorrente, também, na representação das manifestações cívicas que precedem a radicalização armada e, depois, se repete na cobertura da mobilização estadual para o confronto. O povo de São Paulo, em detrimento da articulação exercida pela LDP e a FUP, é retratado como o protagonista da campanha. As divisões internas de classes e de grupos, quando são vislumbradas, representam apenas sinônimos das diferenças naturais entre as pessoas. ${ }^{9}$ Fica submerso, assim, todo o percurso prévio da ação oposicionista.

O vigor do campo interpretativo, criado a partir destas representações visuais - que servem tanto para incitar ânimos, quanto para tornar hegemônica uma determinada leitura da conjuntura -, é difícil de ser transposto, à medida que os eventos cívicos retratados, de fato, trazem à tona momentos de congregação social e expressam, possivelmente, a busca por rearranjos na temerosa ordem político-econômica de 1932. Todavia, como já assinalado antes, o desencadeamento da contestação ao tenentismo, muito antes da população pegar em armas, e os destinos da campanha ficam sob o controle vigilante de entidades que aglutinam as elites paulistas e, ardilosamente, exploram os elementos disponíveis, a fim de canalizá-los na direção almejada.

Uma análise mais abrangente da documentação do período ajuda a explicitar tal fato. Nos testemunhos dos coronéis da Força Pública de São Paulo Heliodoro Tenório da Rocha Marques e Odilon Aquino de Oliveira, os quais estiveram envolvidos nas conspirações a ponto de sofrerem represálias após seu desfecho, fica patente que o episódio chave de 23 de maio, representado como expressão do protagonismo popular, teria sido arquitetado pelos organizadores da oposição política (TENÓRIO; OLIVEIRA, 1933, p.163-164).

Dessa forma, se nos limiares de 1932 a contestação ao Governo Provisório atendia a motivos específicos de políticos e outros grupos insatisfeitos, ao longo do semestre o apelo à tradição regional canalizará os problemas difusos na conjuntura em prol da ação oposicionista, que tem como corolário a panaceia constitucional. Nesse processo, a apropriação dos recursos visuais será peça importante na tarefa de unificar e tornar hegemônica uma interpretação política do cenário vivido e, assim, afastar a ameaçadora pecha de politicagem mesquinha, em favor da representação de um movimento de origem popular.

Em meio ao dito e não dito, à simplificação dos problemas concretos e à omissão dos articuladores e responsáveis diretos pela ação, a representação visual assume valia tal, a ponto de auxiliar o adensamento da campanha constitucionalista, que se torna mote de beligerância em 9 de Julho. Cumprida a etapa preliminar, a eclosão da luta cobrará o desdobramento da representação 
visual em propaganda de massa, contingência que passa pela delicada e indispensável arregimentação dos ecléticos produtores de signos culturais.

\section{Produção cultural beligerante: artistas e intelectuais em ação}

Os esforços dispensados pela FUP e a LDP no sentido de articular a propaganda durante o levante não se pautaram por ações sigilosas. A criação da MMDC, envergando as iniciais dos primeiros mártires da causa - Martins, Miragaia, Dráuzio e Camargo - mortos em 23 de maio pelos inimigos de São Paulo, ${ }^{10}$ desvela, meridianamente, a decisão de se preparar para a sublevação.

À entidade caberia unir e coordenar, por incumbência da FUP e em parceria com a LDP, as atividades até então desenvolvidas difusamente por variados grupos, no sentido de defender as terras bandeirantes. Não raro, ela logo passou à ação, com a organização de comissões estratégicas, entre as quais se destacaria, ao lado dos setores de logística, o Departamento de Propaganda Cívica $^{11}$.

A importância conferida a este departamento pode ser aferida tanto pelas funções que lhe são atribuídas, encarregando-se de divulgar as ideias constitucionalistas e esclarecer a opinião pública, junto ao serviço de alistamento, quanto pelos membros que a ele agregar-se-iam a exemplo de Plínio Barreto e Júlio de Mesquita Filho, este último diretor-proprietário do jornal O Estado de S. Paulo que participara de todo o processo de conspiração e detinha vasta rede de relações no âmbito intelectual.

Para ampliar o escopo de ação, na prática o Departamento de Propaganda da MMDC manteria vínculos estreitos com o serviço de publicidade criado pela LDP, o qual contava predominantemente, desde a primeira hora, com a presença de membros da cúpula diretiva de $O$ Estado de S. Paulo, inclusive com Paulo Duarte, e a colaboração de intelectuais regionalistas, como Alfredo Ellis Junior - defensor do confederacionismo - e Guilherme de Almeida, entre outros.

Esta aliança eloquente entre os membros do jornal O Estado de S. Paulo e os intelectuais regionalistas nos setores de propaganda da MMDC e da LDP, tendo em vista o diagnóstico apresentado anteriormente, por certo não é fortuita. O jornalista Vivaldo Coaracy, por exemplo, que era articulista do periódico e membro da LDP, ainda em 1931 lançou o polêmico livro O Caso de S. Paulo, propondo-se a explicar a realidade política nacional. Coletando diversos artigos publicados em O Estado de S. Paulo, Coaracy não escondia a simpatia pelas ideias confederacionistas:

Enquanto outras unidades do país permanecem nos estados prévios de civilização em graus evolutivos inferiores, alguns destes representados por actividades que Alberto Torres, numa expressão pitoresca e feliz, qualificou de 'assalto à natureza', 
outras entregues aos longos lazeres semi-nômades do pastoreio, outras ainda já fixadas no sedentarismo da cultura sistemática da terra; São Paulo envereda decisivamente pela fase industrial da civilização...

Para que não se destrua a obra realizada; para que prossiga a marcha evolutiva; para que se edifique uma civilização brasileira neste recanto da América; é necessário, é imprescindível que S. Paulo reconquiste o lugar que lhe compete e pertence dentro da Federação, o posto de orientador, de guia e condutor da marcha do Brasil. É mais do que um direito seu, dado pela sua civilização, comprovado pelo seu passado. É uma necessidade histórica para que este país não desminta o destino a que pode aspirar (COARACY, 1931, p. 38).

A matriz desta interpretação, contudo, não deve ser buscada apenas na postura liberal adotada pelo jornalista, sob o aval do periódico. Ela deita raízes na tradição literária regionalista, cujo desdobramento nos anos de 1920 culminou na corrente modernista verde-amarela. ${ }^{12}$ Caberia ao já mencionado Alfredo Ellis Junior, que não tinha participado diretamente do modernismo, mas integrara-se ao verde-amarelismo, pouco depois, partilhando das discussões de homens como Menotti Del Picchia, Cassiano Ricardo, Candido Mota Filho e Plínio Salgado, a contribuição decisiva para o enlace político entre a LDP/ O Estado de S. Paulo e a corrente verde-amarela.

É desta junção que se faz a fecunda confluência entre os escritos ufanistas e os destinos da política estadual, como destaca Antônio Celso Ferreira:

Os verde-amarelos converteram o nacionalismo em programa de ação, empreendendo um verdadeiro culto às tradições brasileiras. Isto os levaria a uma defesa sem disfarces do regionalismo.

[...] a redescoberta da nacionalidade, perseguida no modernismo enquanto ruptura com as convenções em diferentes pontos de vista críticos, ganhou na nova vertente sentido unívoco de retorno à tradição e à ordem, com sérias implicações políticas. As suas propostas possibilitaram a aproximação do modernismo com as correntes políticas e intelectuais conservadoras de São Paulo, num enlace que alcançou o êxtase em 1932 (FERREIRA, 2002, p. 328-329).

Em grande medida, esta parte da intelectualidade paulista cedo se alinhou ao departamento de propaganda da MMDC e da LDP, participando de toda a produção cultural oficial da campanha, sobretudo na difusão da imagem retórica formulada. Assim, ao que parece, estes segmentos, movidos por convicções ideológicas, constituíram o núcleo da propaganda constitucionalista, sendo responsáveis por papéis preeminentes na tarefa.

Todavia, uma vasta gama do material publicitário veiculado durante o levante, composta por cartazes com ilustrações e caricaturas, pinturas, embalagens de produtos industrializados, insígnias, emblemas, fotografias em jornais e revistas, dinheiro cunhado pelos insurrectos, produção fotográfica, fonográfica e radiofônica, advieram, ecleticamente, de artistas e intelectuais que 
aderiram à causa somente quando os confrontos já se desencadeavam, sem necessariamente partilharem das mesmas concepções estéticas e ideológicas.

Mediante a isso, ficam pendentes algumas questões: Quais os tipos de vínculos que tornaram tais grupos solidários à insurreição? Pode-se asseverar que eles seguiam regras ditadas pela MMDC/LDP para a produção cultural constitucionalista ou criavam mais livremente, motivados por sua sensibilidade artística, já que, conforme uma parte da historiografia, estaria em curso uma guerra democrática e espontânea?

Esclarecer a contribuição dos diversos artistas da época e esmiuçar a eclética participação da intelectualidade na luta é tarefa para outro trabalho, contudo, lançar luzes sobre algumas das redes de relações que se estabelecem no entrincheiramento parece fundamental para compreender o caráter do levante e explicar como se sustentam e se reproduzem as representações retóricoimagéticas a respeito do mesmo.

Este aspecto ainda é pouco explorado pela historiografia. Marco Antônio Villa apenas sugere o potencial das redes de sociabilidade no levante em apreço quando aborda a inserção de Mario de Andrade, no entanto, a análise carece de profundidade. Em carta enviada a Paulo Duarte de $O$ Estado de S. Paulo - no mês de agosto de 1932, quando este já se incorporara a um dos batalhões constitucionalistas, Mario de Andrade assevera:

Minha vida se passa aliás nos trabalhos da Liga de Defesa Paulista, pra onde os amigos me mobilizaram. E graças a Deus, porque o início da guerra me deixou meio tonto, sem saber que destino tomar pra ter alguma utilidade. Agora, tenho consciência que trabalho, que sou de alguma forma útil, muito embora minha utilidade nem de longe se compare com o maravilhoso gesto de vocês que são soldados (VILLA, 2008, p.78).

Ora, a MMDC e a LDP são, ao que parece, espaços privilegiados de sociabilidade dos produtores de signos culturais, que vão sendo encaminhados, por meio de relações interpessoais, a atividades ligadas aos departamentos de publicidade e propaganda. Emblemático, nesse sentido, é conhecer o perfil do Jornal das Trincheiras, organizado por obra da LDP, para o qual Mario de Andrade foi conduzido por seus amigos.

Ainda que o jornalzinho não explicite os nomes de seus responsáveis e colaboradores, parece claro que sua redação estava subordinada ao serviço de publicidade da Liga. Além disso, também apresenta fortes laços com O Estado de S. Paulo, sugeridos graças às poucas matérias que aparecem assinadas - sendo duas delas por articulistas seus: Vivaldo Coaracy e Guilherme de Almeida - e, ainda, ao fato da própria impressão ser realizada nas modernas oficinas gráficas dos Mesquitas. 
Tradição e Retórica Imagética: a construção da propaganda visual oposicionista no levante de 1932 em São Paulo

Ao todo o Jornal das Trincheiras veiculou treze números enquanto houve confronto, espalhados duas vezes por semana pela capital paulista e as principais zonas de combate, visto que era intenção da LDP fazer do jornalzinho um aliado na peleja contra o Governo Provisório, esclarecendo a todos - e principalmente aos combatentes - a respeito da natureza da luta. Sua função no ciclo da propaganda era corroborar as mensagens lançadas pelas rádios paulistas e desmentir a contra-ofensiva perpetrada pelas ondas radiofônicas cariocas (TOTA, 1990).

Mario de Andrade, conforme escrevera em missiva a Paulo Duarte, se envolveu profundamente na redação do Jornal das Trincheiras. Tendo em vista sua condição de alheamento a todo o processo conspiratório, a análise das representações e práticas difundidas pelo departamento ao qual se filiou permite exemplificar as condições de incorporação dos intelectuais que aderiram ao levante e a escassa flexibilidade da retórica introjetada.

Embora não seja possível assinalar de quais matérias ou colunas Mario de Andrade participou, pois a maioria permanecia no anonimato, é de se supor que ele não ignorava a linha editorial da publicação a que dedicava parte de seu dia. O trecho a seguir permite aferir os limites da campanha movida pelo jornalzinho:

[...] um conflicto entre duas phases secularmente distanciadas de civilização, atiradas face a face por uma contingência histórica para não dizer entre a civilização e a barbárie ...

Em todos os ambientes sociaes em estado dynamico, evolutivo, existem, a par da elite que se mantem acima da média de civilização do ambiente e constitue o fermento da evolução, a grande massa inferior dos que não podem attingir a essa média, dos inadaptáveis, dos dominados pelos complexos atávicos, dos estados primitivos, que se rebellam contra a civilização e procuram rebaixar o meio social a um grau inferior, num retrocesso degenerativo, para a plena expansão dos seus apetites, das suas paixões, dos seus instinctos (JORNAL DAS TRINCHEIRAS, 25/09/1932)

Artigos deste teor, de forma alguma, são esporádicos no Jornal das Trincheiras. Fato é que os seus articuladores utilizavam-se da linguagem imagética para ampliar e melhor fixar os discursos e, não raramente, o tom regionalista exacerbado descambava para o preconceito. Tratando-se de definir o perfil do soldado ditatorial, a representação visual concentra-se propositadamente nos batalhões provenientes da região nordeste, ainda que elas não representassem a maior parte das tropas. Na imagem a seguir este recurso apresenta-se com meridiana evidência: 


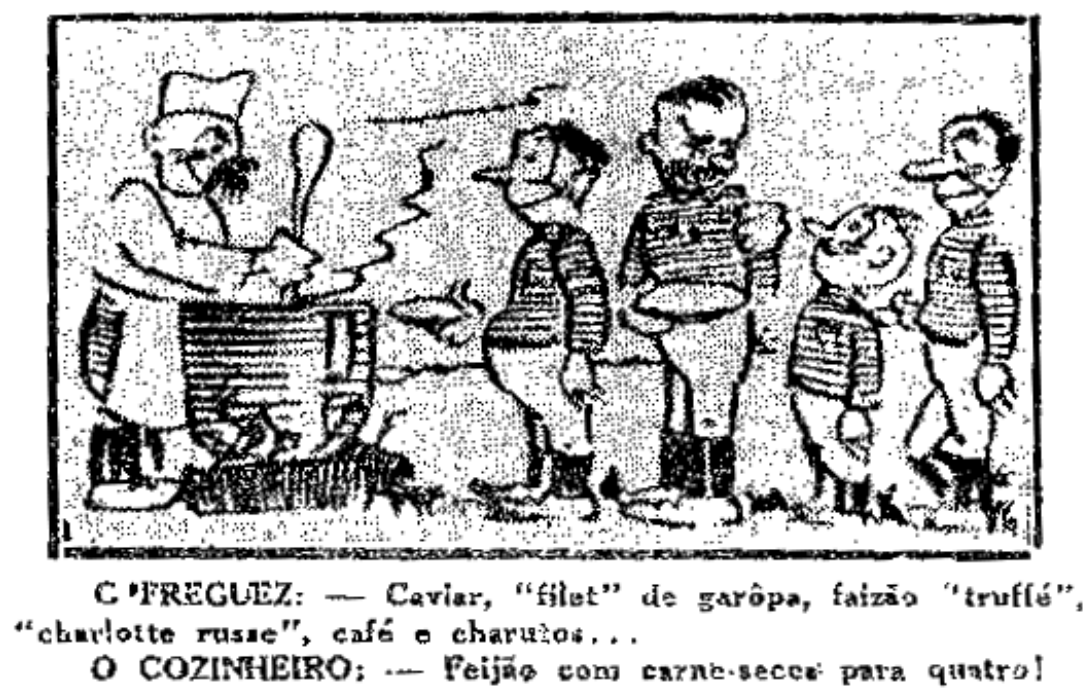

FIGURA 5: Soldados Ditatoriais.

Fonte: Jornal das Trincheiras, 28/08/1932. p.4

Logo na chegada às zonas de operações militares (Figura 5), os recrutas do Governo Provisório demonstram o principal objetivo que os motivaria a aderir à luta: a comida. No entanto, a difícil realidade não demora a lhes ser apresentada, e com certo rigor, na medida em que esperavam encontrar um verdadeiro banquete real (que, possivelmente, lhes havia sido prometido) e são acometidos pela refeição trivial, típica de sua terra natal. Ou seja, vieram combater enganados.

Em que pese à caracterização, os adversários de São Paulo são tidos por homens de estatura mediana ou, excessivamente, baixa para o combate, magros e barrigudinhos (talvez, pelo contágio de vermes), trajando, todos, os mesmos uniformes em farrapos e inadequados para a vida no front.

As discrepâncias entre a representação e a realidade, neste caso, são evidentes, afinal, é óbvio que o exército que permaneceu fiel ao Governo Provisório não se constituía apenas de tropas nordestinas e que os grupos que de lá vieram não se enquadravam, necessariamente, ao perfil com que eram representados. Todavia, o discurso imagético ganha significado nítido na linha editorial assumida pelo Jornal das Trincheiras, como um prolongamento da retórica cunhada pela LDP antes mesmo do confronto ser iniciado. Se outrora fora afirmado que o esplendor de São Paulo dependia dos paulistas, no momento de maior radicalização esta imagem é superdimensionada - vale até emprestar ideias confederacionistas - para incitar no voluntariado e nos demais combatentes os rancores, ódios e temores com relação aos adversários, sintetizados nos nordestinos, cujo fluxo imigratório para São Paulo já se desencadeara nos anos de 1930.

Com efeito, para além de satirizar os ditatoriais, o jornal demonstrava o propósito de designar as diferenças na constituição física dos combatentes. Tudo os opunha. São Paulo se batia pelas garantias do Estado de Direito, os inimigos teriam ideais vagos e irrisórios, como a comida; os 
paulistas eram combatentes preparados materialmente e de estirpe cheia de viço, enquanto a ditadura teria que se arranjar com tropas famintas e de soldados débeis fisicamente. Lutar contra eles implicava a certeza da vitória.

Essa argumentação se repete, inclusive, na última edição do Jornal das Trincheiras, em 25 de setembro, quando Jeremias e Zoroastro, recrutas nordestinos que lutam pelo Governo Provisório, são aprisionados pelos paulistas.

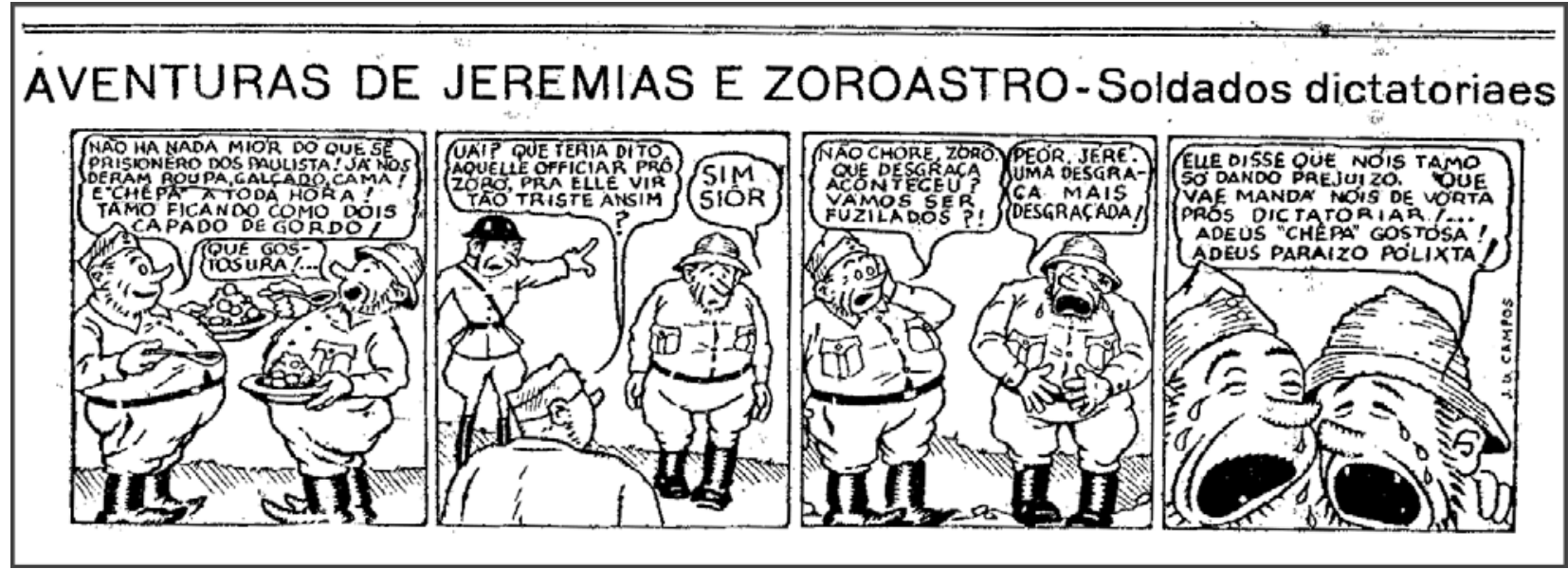

FIGURA 6: As aventuras de Jeremias e Zoroastro. Fonte: Jornal das Trincheiras, 25/09/1932.

Mais uma vez o contraste entre o avanço material das terras bandeirantes e o atraso da região Norte é explorado. A despeito da precária condição física com que foram capturados, em São Paulo recebem vestimentas adequadas e alimentação farta, indícios da pujança bandeirante, onde há excedentes para alimentar até os inimigos.

Deste modo, Jeremias e Zoroastro representam visualmente a suposta incapacidade que o restante do país, sobretudo o Brasil do Norte, teria de se autossustentar, recorrendo aos cofres materiais de São Paulo e constituindo-se em um peso desnecessário para ele. A missão de combater a carga mórbida caberia aos soldados nas trincheiras, já que era situação cômoda para Jeremias e Zoroastro, brasileiros de sotaque carregado e cheio de incorreções (por incapacidade intelectual?), permanecer vivendo às expensas paulistas.

O agravamento do conflito, por conseguinte, acirrou a representação proselitista veiculada na gênese da campanha oposicionista por palavras e imagens. No calor da luta, os objetivos constitucionais perdem espaço para o apelo formulado pelas correntes políticas e intelectuais regionalistas à paulistanidade, eivada visceralmente por acentuado etnocentrismo. O vigor desta posição, que assume nuances regionalistas ora radicalizadas, ora mais brandas, é proeminente nos 
departamentos de propaganda e publicidade da LDP e da MMDC, perpassando os grupos e indivíduos que aderem à causa.

A incorporação de Mario de Andrade à LDP, atuando no Jornal das Trincheiras, desvela a força desses liames que conjugam os constitucionalistas e reproduzem a retórica perpetrada. Por mais que a sua adesão ao levante seja espontânea, por laços de amizade ou sensibilização, ele não age, a partir de então, a seu bel prazer. Ao contrário, é mobilizado para um jornalzinho extremamente importante, cuja linha editorial expressa a leitura oficial da LDP, agravada por teores acerbamente regionalistas, e auxilia ao êxito da publicação. Casos como este não são exceções, haja vista as diversas contribuições de intelectuais e artistas que a LDP e a MMDC recebem, enquadrando-os a seus padrões. ${ }^{13}$ Divergências ou omissão são tratadas como traição. Com isso, a propaganda constitucionalista encontra forças para atingir seus objetivos. Passemos ao exemplo.

\section{Cartões e Propaganda postal Constitucionalista}

Avaliar a abrangência das hipóteses levantadas demandaria a análise da variada produção cultural veiculada ao longo da pugna, notadamente no âmbito da linguagem imagética. Mediante a extensa gama de fontes disponíveis, este trabalho ater-se-á, no entanto, à análise de alguns cartões postais proselitistas - representativos das nuances da propaganda constitucionalista - pela relevância e abrangência que gozaram durante o período de confrontos.

Veja-se, abaixo, a representação visual construída em um simples cartão postal do Correio Militar MMDC.

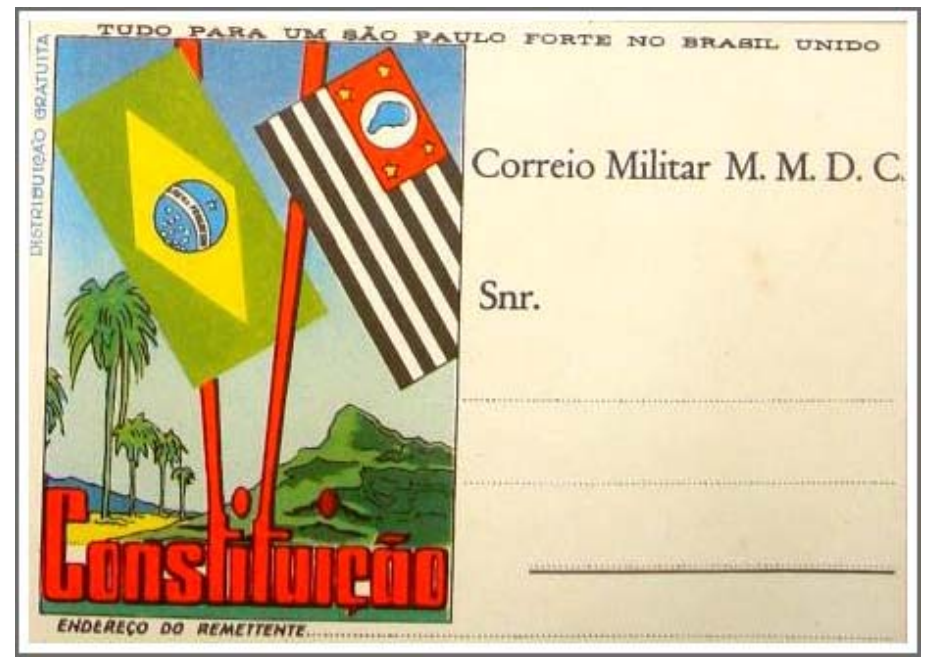

FIGURA 7: Cartões Postais. São Paulo: MMDC, 1932. 
É possível detectar, ao menos, três apelos visuais na mensagem. No primeiro, a palavra Constituição - em atraente vermelho - muito mais do que evocar debates sobre fórmulas constitucionais e legislativas rememora a possibilidade de São Paulo voltar ao poder, mediante as garantias do Estado de Direito e, quem sabe, avançar na resolução dos problemas concretos que a todos afligia no início dos anos trinta. Em seguida, as bandeiras de São Paulo e do Brasil aparecem, lado a lado, unidas por um atrativo jogo de cores com a palavra Constituição, ou seja, fica evidenciado que a lei é de interesse de ambos e, por conseguinte, o levante é legítimo, uma vez que a São Paulo, como precursor, caber-lhe-ia o dever de indicar o caminho ao Brasil. Por fim, almejase combater a contrapropaganda feita pelo Governo Provisório a respeito do separatismo, investindo na imagem da complementaridade, já que tão nobre causa merecia todo o entusiasmo dos paulistas.

As razões para o entusiasmo das tropas advinham não apenas da certeza de se bater por uma causa lídima, mas pela confiança de que São Paulo, em sua pujança, não desampara. Pelo menos era isso que a MMDC asseverava (ver Figura 8 abaixo).

Em tempos de incerteza e de afastamento dos seus, o apelo emocional fica nítido na imagem, a partir da suposta identidade orgânica entre o soldado, seu filho e seu estado. Projeta-se, com clarividência, a ideia de uma grande rede de solidariedade familiar e de reciprocidade que obriga afetivamente o combatente a se empenhar, na medida em que a família paulista ampara, alimenta e protege o seu rebento, em primeiro plano, é função do soldado, na parte superior, como que em posição angelical, velar pelas famílias paulistas. Há, ainda, o efeito das cores do uniforme do soldado e o pano de fundo, talvez, em alusão à defesa do Brasil.

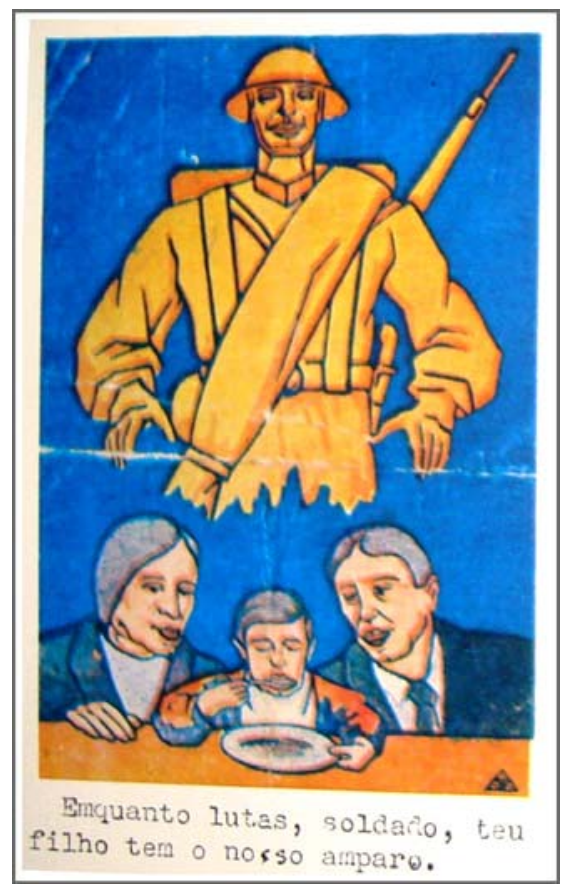

FIGURA 8: Cartões Postais. São Paulo: MMDC, 1932. 
O tom de cobrança e de responsabilidade também se evidencia no apelo à tradição regional. Lutando com todas as suas forças ou apoiando, decididamente, na retaguarda, o paulista estaria se incorporando a plêiade de notáveis da tradição regional:

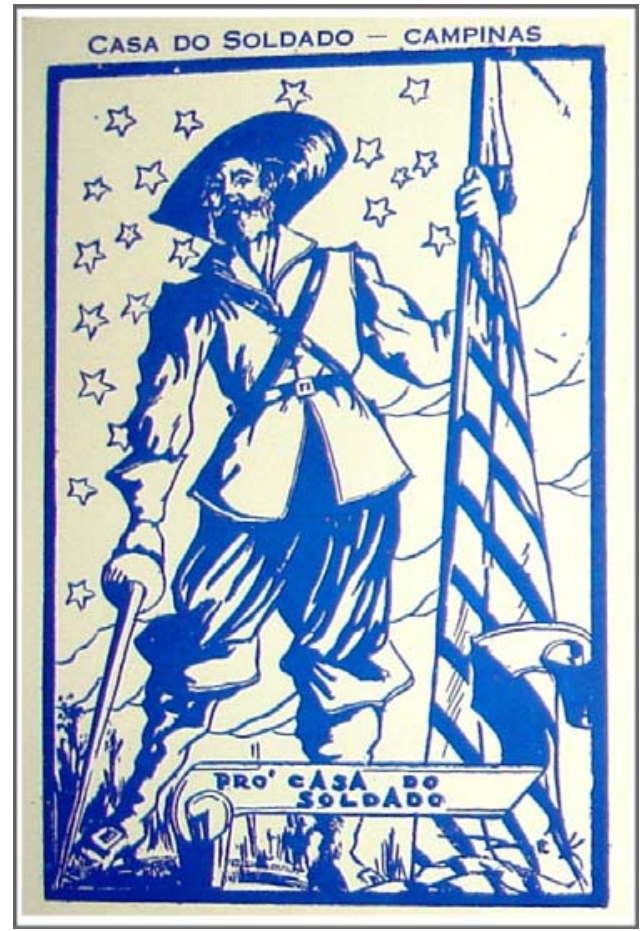

FIGURA 9: Cartões Postais. São Paulo: MMDC, 1932.

Neste cartão, os próprios bandeirantes são trazidos para o contexto da sublevação. Se outrora eles expandiram as fronteiras do estrelado território nacional e, com sua valentia, teriam defendido, à espada, a bandeira de São Paulo, fica subjacente que, desta vez, a missão fora legada ao soldado constitucionalista. Como não lutar por São Paulo se até os mortos cobravam isso? A mensagem inicial, portanto, fora potencializada e traduzida para o confronto, afinal “o esplendor de São Paulo depende dos paulistas”.

Cumpre observar que, em concomitância com as criações sob chancela do correio militar MMDC, corriam livremente cartões-postais sem indicação de autoria, sustentando temas e perspectivas radicalizadas, bem próximas daquelas preconizadas pelo Jornal das Trincheiras. Em um dos cartões, trazia-se o desenho de uma vaca com tetas cheias de leite e cercada por um grupo de crianças, alegres e bem nutridas, incluindo uma enigmática figura escura. Apesar de seu vigor, a vaca encontra-se amarrada pelo pescoço e com a língua de fora, praticamente enforcada, curiosamente, pela única criança que está de botas (alusão a Getúlio Vargas e a tradicional vestimenta gaúcha?). 


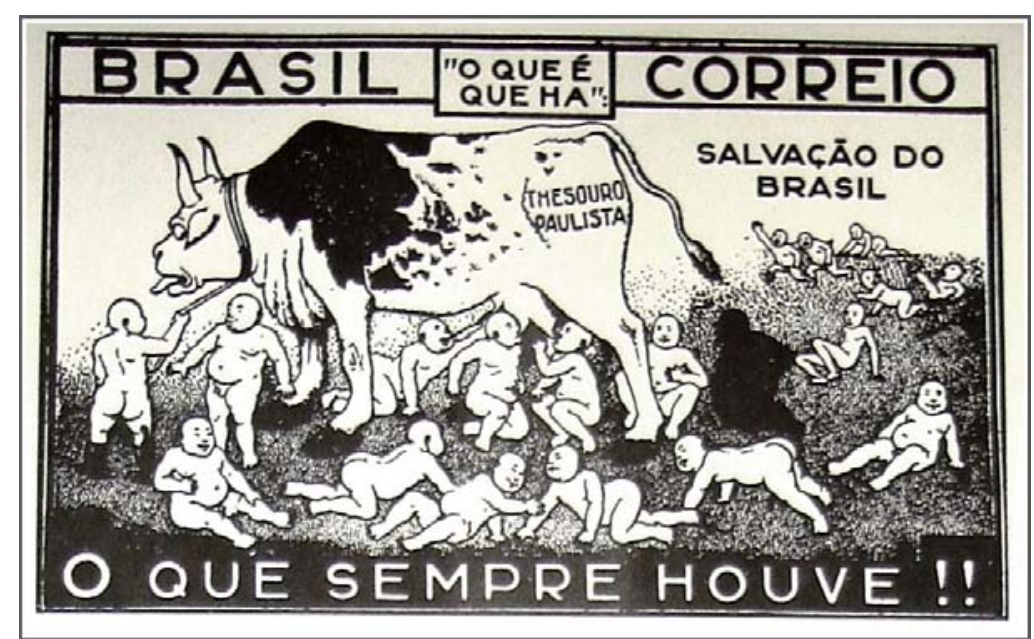

FIGURA 10: Cartão postal. S.n.t

A ambiguidade da cena almeja, sem dúvida, demonstrar de forma impactante a necessidade de mudanças na política nacional, haja vista que, tal como estava, São Paulo alimentava todos os outros Estados, que nenhum benefício lhe traziam.

Outro cartão-postal seguia princípios parecidos, ironizando os inimigos da lei com caricaturas que destacavam a impotência do Governo Provisório, formado por membros de outras regiões, os quais se ajoelhariam por clemência (ver Figura 11, abaixo) perante São Paulo. Mesmo o que era praticamente impossível, como a vitória bélica paulista, fora apresentado como já assegurado.

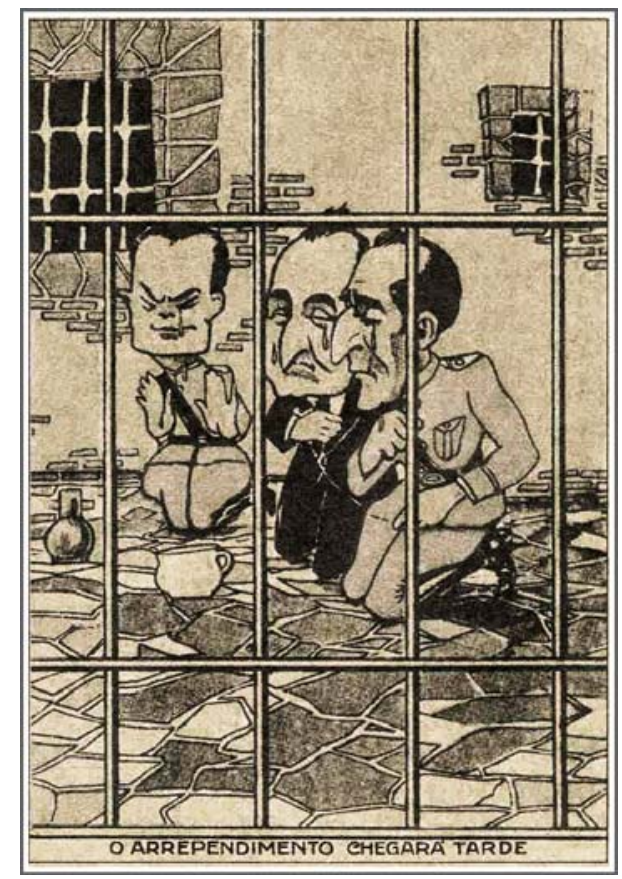

FIGURA 11: Cartão-Postal. Da esquerda para a direita: major Juarez Távora, Getúlio Vargas e o coronel João Alberto Lins de Barros. Fonte: MEC/ FUNARTE, 1982. 
Obviamente, os cartões-postais deste tipo não eram produzidos pelo Governo Provisório, nem exemplares raros. Constituem, por conseguinte, protótipos dos produtos culturais da propaganda constitucionalista e das nuances que lhe perpassam, de acordo com a conjuntura beligerante. A própria diversidade de cartões veiculados é maior; todavia, em grande medida, reproduzem e legitimam interpretações cunhadas antes do troar dos canhões.

O levante paulista de 1932 terminou fracassado do ponto de vista militar. A despeito da derrota, no entanto, a imagem preservada para a posteridade jamais admitiu máculas ao ideal que teria movido São Paulo ao confronto, uma vez que este havia sido vitorioso na Constituinte de 1933/34, exclusivamente em função da brava luta movida pelos paulistas.

Entre os elementos preservados, não raro, figuram aqueles que fizeram parte da ardente campanha coordenada pela LDP e a MMDC, desde os limiares de 1932. Nesta visão, a Revolução de 1930 fora desvirtuada em seus propósitos pelo despreparo do tenentismo para os postos de comando que ocupava, sob o olhar cúmplice de Getúlio Vargas. Constituição e Ordem apresentaram-se como opções mais viáveis para recolocar o país no caminho do progresso e, por isso, o povo de São Paulo, ferido pelos agravos a sua terra e as humilhações às suas nobres tradições, resolveu, forçosamente, pegar em armas e, uma vez mais, defender o Brasil, restabelecendo nele o arbítrio da lei.

O êxito desta interpretação entre os contemporâneos, por sua vez, está fortemente associado aos desarranjos político-econômicos atravessados por São Paulo e o Brasil no início dos anos de 1930 e a apropriação da tradição e do imaginário regional, em convergência com os anseios de mudança e a esfera de ressonância criada. A propaganda constitucionalista procurou explorar e canalizar esses valores, valendo-se das várias linguagens e discursos orais, escritos e visuais, nas rádios, jornais e demais impressos.

Com efeito, a visão, como campo privilegiado, foi assediada pelos articuladores do confronto insistentemente, a partir de todos os recursos disponíveis à época. Era preciso vencer a batalha do convencimento. Para isso, representaram-se visualmente paulistas como bandeirantes e brasileiros como oportunistas, os tenentes, demonizados, viraram vilões e os políticos do PRP, antes desprezados, a partir de então injustiçados. Asseverou-se até mesmo que o levante fora movido pelas diretrizes populares.

Enquanto isso, na LDP e na MMDC intelectuais e artistas se multiplicavam na tarefa de fortalecer a propaganda constitucionalista, sobretudo no âmbito visual. Incorporados, por sensibilização ou redes de sociabilidade, todos ficaram presos, no entanto, às coordenadas do comitê diretivo, aglutinador das elites paulistas. A análise do Jornal das Trincheiras e dos cartões 
Tradição e Retórica Imagética: a construção da propaganda visual oposicionista no levante de 1932 em São Paulo

postais, oficiais ou não, desvela as nuances do discurso acentuadamente regionalista, que foi endossado pelos que aderiram à campanha.

Tal o vigor do vivido que os ecos da imagem vigiada e explorada ainda se reproduzem pelos domínios da memória e da historiografia. Todavia, sob a representação cadavérica da Constituição, da Democracia e da hegemonia popular pululam, braços dados com as memórias subterrâneas, imagens nem tão atraentes dos que acreditaram no caráter democrático do entrincheiramento e viram a vitória da bancada patronal e de seus projetos na Constituinte de 1933/34, sinal claro dos interesses não ditos e das contradições ideológicas, condição de existência da imagem gloriosa do levante paulista.

\section{Notas}

${ }^{1}$ Emília Viotti da Costa havia assinalado as dificuldades na própria composição do grupo que apoiou a revolução de trinta: “A oposição era um amalgama de interesses os mais contraditórios e dos mais variados projetos. Por um momento todos se tinham unido para derrubar o governo, mas encerrada esta fase, os conflitos já emergiam”. (COSTA, 1982. p. 9).

${ }^{2}$ Conforme levantamentos censitários do município de São Paulo, nos anos de 1920 a população da cidade era de 539.033, enquanto em 1940 este número subiu para 1.326.261. Histórico Demográfico do Município de São Paulo. Disponível em: http://sempla.prefeitura.sp.gov.br/historico/tabelas/pop brasil.php Acesso em: 18/01/2010.

${ }^{3}$ Assinam o manifesto de fundação da Liga, em maio de 1931, mais de quatrocentas pessoas, entre elas Paulo Duarte, Alfredo Ellis Junior e Abelardo Vergueiro César. Júlio de Mesquita Filho, diretor geral de $O$ Estado de S. Paulo, também foi um dos seus principais articuladores. Aliado dos revolucionários de 1930, quebraria seu apoio aos tenentes junto ao PD, em abril de 1931, ocasião em que passariam a trabalhar pela criação da LDP. (ABREU, A. A.; LAMARÃO, S. T. N.; WELTMAN, F. L.; BELOCH, I., 2001. p. 3117; 3789).

${ }^{4}$ A acusação imputada aos tenentes relativa à sua tendência comunista pode ser compreendida no contexto do período em que os mesmos fazem a Revolução de 1930. Havia grande temor de que o "tenentismo" debandasse para regimes totalitários, como o fascismo ou comunismo, e como João Alberto, o primeiro interventor em São Paulo no governo Vargas, aproximou-se, inicialmente, do Partido Comunista, os tenentes foram classificados como "extremistas" pelo jornal O Estado de S. Paulo. Porém, se para a população o comunismo era apresentado como algo perigoso, isso se explica considerando que tal "radicalismo" derivava da defesa de ideias relacionadas a mudanças na estrutura social e na constituição da legislação trabalhista, por meio de medidas em favor dos trabalhadores como, por exemplo, o direito de férias. (PRADO; CAPELATO, 1980. p.43-44).

${ }^{5}$ O contemporâneo Eduardo Dias, em suas memórias, fornece uma definição emblemática da situação dos trabalhadores ainda no início dos anos trinta. "O ano de 1931 fora de muita dificuldade. O desemprego era em massa. Os que tinham serviço eram só três dias por semana. Nas portas das fábricas, multidões passavam o dia todo, esperando vaga... as coisas de primeira necessidade escasseavam na maioria das famílias... na nossa não era diferente. Agrupamentos nas esquinas. Nas portas das casas os vizinhos todos na rua”. Citado por ALMEIDA, 1999. p.141.

${ }^{6}$ Entre os oradores da ocasião estão Almeida Junior (Sociedade de Cirurgia e Medicina de S. Paulo) e Antônio Augusto Covelo (Instituto da Ordem dos Advogados de S. Paulo). Além de advogado, A. A. Covelo também trabalhou em diversos jornais de São Paulo e fora um dos deputados paulistas alijados do cargo pela Revolução de 1930. O Estado de S. Paulo, 26/01/1932. 
${ }^{7}$ Esta análise difere, portanto, da perspectiva adotada, sobre a mesma imagem, por DE PAULA, 1999, p.226-227.

${ }^{8}$ Sobre isso ver: FERREIRA, 2002; LUCA, 1999; SCHWARCZ, 1993; DEAECTO; SECCO; SILVA; GLEZER (Orgs.), 2008, entre outros.

${ }^{9}$ Holien Gonçalvez Bezerra ressaltou a força ideológica do argumento relativo à participação popular, nas obras de memorialistas. (BEZERRA, 1988).

${ }^{10}$ Veja-se como o jornal O Estado de S. Paulo interpretou os acontecimentos de 23 de maio: "Tudo que era nosso, os nossos recursos financeiros, as armas dos nossos soldados, a liberdade e a vida dos nossos cidadãos, ficou, durante esses longos meses sombrios, ao serviço de um caudilhismo vexatório e doloroso. Por causa desse caudilhismo, e para lhe saciar a sede, sangue paulista, o generoso e quente sangue da mocidade, foi derramado nas ruas desta capital”. O Estado de S. Paulo, 25 de maio de 1932.

${ }^{11}$ Reflexões mais aprofundadas neste sentido foram desenvolvidas em ampla pesquisa para a consecução de minha tese de doutorado. (RODRIGUES, 2009).

${ }^{12} \mathrm{O}$ Grupo de intelectuais que forneceria subsídios mais acentuados à LDP adviria das divisões do modernismo. Alfredo Ellis, Cassiano Ricardo, Candido Mota Filho, Plínio Salgado e Menotti Del Picchia formariam a corrente Verde-Amarela "que sustentava a exaltação das tradições culturais brasileiras, contrastando com o criticismo 'antropofágico' do grupo Pau-Brasil, coordenado por Oswald de Andrade, Mario de Andrade e Raul Bopp”. Em 1932, a defesa da nacionalidade se confundiria com a luta pelo federalismo na ótica do "verde-amarelismo", expressando-se no aval do grupo a solução armada. Pouco mais tarde, os intelectuais egressos do "verde-amarelismo" constituiriam o grupo Bandeira, com considerável influência sobre a formação do integralismo. (ABREU; LAMARÃO; WELTMAN; BELOCH, I. (Orgs.), 2001. p.3117).

${ }^{13}$ Cumpre esclarecer que nem todos os intelectuais e artistas de renome de São Paulo estiveram favoráveis ao confronto. Oswald de Andrade, por exemplo, não escondeu a discordância dos ideais da luta e Tarsila do Amaral, após retornar de sua viagem à União Soviética, chegou a ficar um mês presa no ano de 1932, por suas posições ideológicas. (TORAL, 2004).

\section{Referências}

ABREU, A. A. et. al. (Org.). Dicionário Histórico-Biográfico Brasileiro pós-30. 2ª ed., RJ: FGV, 2001. p.3117; 3789.

ALMEIDA, I. B. da S. O olhar de quem faz: o paulistano sob a ótica do operariado paulista durante a Revolução Constitucionalista de 1932. 1999. Dissertação (Mestrado em História) Faculdade de Filosofia Letras e Ciências Humanas - Universidade de São Paulo, São Paulo, 1999.

BACZKO, B. Imaginação Social. In: Enciclopédia Einaudi, Lisboa: Imprensa Nacional - Casa da Moeda, v.5, 1984.

BEZERRA, H. G. O Jogo do poder: Revolução Paulista de 32. SP: Moderna, 1988.

COARACY, V. V. O Caso de São Paulo. São Paulo: Ferraz, 1931.

COSTA, E. V. 1932: Imagens Contraditórias. São Paulo: Arquivo do Estado, 1982.

DE PAULA, J. 1932: Imagens Construindo a História. 2a . ed. Campinas: Unicamp, 1999.

FERREIRA, A. C. A epopéia bandeirante: letrados, instituições, invenção histórica (1870-1940). São Paulo: Unesp, 2002. 
FRANCASTEL, P. A Realidade Figurativa. São Paulo: Perspectiva, 1982.

HISTÓRICO Demográfico do Município de São Paulo. Disponível em:

http://sempla.prefeitura.sp.gov.br/historico/tabelas/pop_brasil.php Acesso em: 18/01/2010.

KOSSOY, B. Realidades e Ficções na Trama Fotográfica. 3ª ed., São Paulo: Ateliê Editorial, 2002.

LUCA, T. R. A Revista do Brasil: Um diagnóstico para a (N)ação. SP: UNESP, 1999.

MARTINS, J. B. Álbum de Família: 1932. São Paulo: Martins, 1954.

MEC/ FUNARTE. Revolução de 32: A Fotografia e a Política. RJ: Funarte FGV/ CPDOC, 1982.

PONTES, J. A. V. O Brasil se revolta: o caráter nacional de um movimento democrático. São Paulo: Editora Terceiro Nome: O Estado de S. Paulo, 2004.

PRADO, M. L. e CAPELATO, M. H. O Bravo Matutino: imprensa e ideologia no jornal "O Estado de S. Paulo”. São Paulo: Ed. Alfa-Omega, 1980.

RODRIGUES, J. P. O Levante “Constitucionalista” de 1932 e a Força da Tradição: Do confronto bélico à batalha pela memória (1932-1934). 2009. Tese (Doutorado em História) - Faculdade de Ciências e Letras de Assis - Universidade Estadual Paulista, Assis, 2009.

SCHWARCZ, L. K. M. O espetáculo das raças. cientistas, instituições e pensamento racial no Brasil: 1870-1930. São Paulo: Companhia das Letras, 1993.

SILVA, M.; GLEZER, R. (Org.). São Paulo - Espaço e História. SP: LCTE, 2008, v. 1.

TENÓRIO, H. e OLIVEIRA, O. A. de (capitão). São Paulo Contra a Ditadura: da invasão revolucionária de 30 à queda do governo Waldomiro e nomeação do Dr. Armando Salles para a interventoria paulista. São Paulo: Ismael Nogueira, 1933.

TORAL, A. A imagem Paulista do Caipira ao Bandeirante. In: CAMARGO, A. M. A. (org). São Paulo, Uma Longa História. São Paulo: CIEE, 2004.

TOTA, A. P. A Locomotiva no Ar: Rádio e Modernidade em São Paulo 1924 - 1934. São Paulo: Secretaria de Estado da Cultura/ PW, 1990.

VILLA, M. A. 1932: Imagens de uma Revolução. São Paulo: Imprensa Oficial do Estado de São Paulo, 2008.

Recebido em: 17/02/2011

Aprovado em: 06/03/2011 